\title{
Difficulties experienced by nursing professionals in the preparation of medicine
}

\author{
Dificuldades vivenciadas por técnicos de enfermagem no preparo de medicamentos \\ Dificultades vividas por técnicos de enfermería en el preparo de medicamentos
}

Ozimar Azevêdo ${ }^{1}$, Cícera Maria Braz da Silva ${ }^{1}$, Leonardo José Dantas Pinheiro de Araújo ${ }^{2}$, Edilma de Oliveira Costa $^{1}$, Maria Isabel da Conceição Dias Fernandes ${ }^{1}$, Ana Luisa Brandão de Carvalho Lira ${ }^{1}$

We aimed at analyzing the difficulties experienced by nursing professionals during the preparation of medication. It is a descriptive study conducted in a university hospital in a city in northeastern Brazil. 25 nursing professionals were interviewed, using a semi-structured interview script, during the months of January and February 2013. The difficulties during the preparation of medicine were: prescription barely legible; labels of medicine with small and similar letters; lack of exclusive venue for this activity; wrong expedition by the drugstore; inadequate lighting, and accumulation of functions. The conclusion is that difficulties related to the pharmaceutical process were identified. So, in order to ensure safe medicine therapy, it is necessary to have mandatory strategies which favor the effectiveness of this process.

Descriptors: Nursing Care; Medication Errors; Pharmaceutical Preparations; Patient Safety.

Objetivou-se analisar dificuldades vivenciadas por técnicos de enfermagem durante o preparo de medicamentos. Pesquisa descritiva, realizada em hospital universitário de cidade do nordeste brasileiro. Foram entrevistados 25 técnicos de enfermagem, por meio de um roteiro de entrevista semiestruturado, durante janeiro e fevereiro de 2013. As dificuldades durante o preparo de medicamentos foram: prescrição médica pouco legível; rótulos dos medicamentos com letras pequenas e semelhantes; ausência de local exclusivo para essa atividade; dispensação errada pela farmácia; iluminação inadequada; e acúmulo de funções. Concluiu-se que foram identificadas dificuldades relacionadas ao preparo de medicamento. Assim, para garantir a terapêutica medicamentosa segura, são imperativas estratégias que favoreçam a eficácia desse processo.

Descritores: Cuidados de Enfermagem; Erros de Medicação; Preparações Farmacêuticas; Segurança do Paciente.

El objetivo fue analizar las dificultades vividas por técnicos de enfermería durante el preparo de medicamentos. Investigación descriptiva, realizada en hospital universitario de ciudad de nordeste brasileño. Fueron entrevistados 25 técnicos de enfermería, a través de un guión de entrevista semiestructurada, entre enero y febrero de 2013. Las dificultades durante el preparo de los medicamentos fueron: prescripción médica poco legible; etiquetas de los medicamentos con letras pequeñas y semejantes; ausencia de local exclusivo para esa actividad; dispensación errónea por la farmacia; iluminación inadecuada; y acumulo de funciones. En conclusión, fueron identificadas dificultades relacionadas al preparo de medicamentos. Así, para garantizar la terapéutica medicamentosa segura, son imperativas estrategias que favorezcan la eficacia de ese proceso.

Descriptores: Atención de Enfermería; Errores de Medicación; Preparaciones Farmacéuticas; Seguridad del Paciente.

\footnotetext{
${ }^{1}$ Universidade Federal do Rio Grande do Norte. Natal, RN, Brazil.

${ }^{2}$ Hospital do Coração. Natal, RN, Brazil.

Corresponding author: Ana Luisa Brandão de Carvalho Lira

Departamento de Enfermagem, Universidade Federal do Rio Grande do Norte. Campus Universitário, S/N - Lagoa Nova. CEP: $59072-970$.

Natal, RN, Brazil. E-mail: analuisa_brandao@yahoo.com.br
} 


\section{Introduction}

Despite the advancement and the technologies currently used in the area of health, the risks inherent to care are present in the everyday activities of the hospital facilities. In this context, the safety of the patient must be a practice inserted in the process of care of the health professionals and must not be understood only as the lack of errors in the assistance to health, but also as the guarantee of a well succeeded care favoring promotion, prevention, protection and recovery of the health of the patient in all levels of care. So, the safety of the patient must be preserved in all therapeutic procedures, above all in the process of preparation and administration of medicine, which involves potential risks to the patient, and it can reverberate in the morbidity and mortality of the same, besides being responsible for $70 \%$ of the iatrogenesis with the patient ${ }^{(1)}$.

The process of administering medicine is outlined as a complex system, of interlinked and interdependent stages and executed by different professionals in the area of health. Among the multiprofessional team, the nursing professionals who constitute the major working force in the area of health are highlighted ${ }^{(2)}$, specifically the nursing professionals and their assistants, health professionals who are responsible for the greatest part of the errors inherent to care, according to a study on iatrogenesis in nursing. They have as attributions, besides other activities, the preparation and administration of medicine; however, this and other practices must be executed under the supervision by a professional with a university degree, such as the nurse, a reality which is not always experienced ${ }^{(1,3)}$.

Although the administration and the preparation of medicine are basic procedures of nursing, they require improvement of the health professional, both regarding the scientific knowledge as well as the techniques of handling and application, prioritizing strategies of prevention of errors aiming at the safety of the patient, linked to that the process of preparation and administration of medicine is liable to present errors, once it is part of the human condition the act of making errors, being influenced both by personal factors as well as by the system which rules the activities to be done ${ }^{(4)}$.

However, concerning the care with the health of the patient, especially the one using medicine therapy, it is mandatory to promote the safety of the patient aiming at the benefits for his health and the success of the assistance. This condition is feasible with the adoption of measures of prevention of errors in the preparation and administration of medicine and strategies of health surveillance and continued education.

Under the perspective of safe care, the process of work of the nursing professionals must be based in the prevention of errors with the purpose to ensure the right to the assistance free of damages thus offering a healthy and safe assistance ${ }^{(4)}$.

The existence of few studies which approached the problem on the difficulties in the preparation of medicine under the view of the nursing professionals was observed in the literature. Furthermore, this thematic of study is inserted in one of the priority lines in research mentioned in the National Agenda of Priorities of Research in Health, released by the Health Department $t^{(5)}$.

Concerning the above mentioned, it is mandatory to promote the safety to the patient during the medicine therapy, whose process can imply in errors and these are influenced by several factors, related to health professionals and physicalstructural and routine aspects. So, it is presupposed that the nursing professionals experienced difficulties during the preparation of medicine, conditions that can favor the occurrence of faults, which, in turn, can reverberate in damages of major or minor seriousness in the life of the patient. In this sense, the following question emerged: which are the difficulties pointed out by nursing professionals during the preparation of medicine?

From that question, the objective of the study is 
to analyze the difficulties experienced by the nursing team during the preparation of medicine.

\section{Method}

This is a descriptive research aimed at observing and describing a specific phenomenon ${ }^{(6)}$. Made in a university hospital located in the northeast of Brazil, whose population was composed, specifically, by 27 nursing professionals of the mentioned hospital and the sample was made with 25 workers. The criteria of inclusion were: to be working during the data collection; to perform activities directly related to the preparation and administration of medicine. The criterion of exclusion was to be younger than 18 years.

The instrument of research used was a semi structured script of interview, having social demographic questions inherent to the object of study. The data were collected until saturation, obtained when no new information emerged concerning one category ${ }^{(7)}$.

The interviews were recorded using an audio digital device, and identified after the transcript by the letter $\mathrm{E}$ followed by a number attributed at random, in order to guarantee the anonymity of the participants. Furthermore, there were notes in the field diary, with the purpose to register complementary information to the reports.

The treatment of the data was made according to the precepts of analysis of content of the classificatory type: the answers to the open question of a questionnaire ${ }^{(8)}$. So, the reports of the subjects were transcript, the nuclei of sense were identified, and later on codified and categorized. From this process, a category was originated: the nursing professionals and their difficulties for the preparation of medicine. Such category was analyzed and discussed from the survey of the literature on the subject, involving the safety of the patient, medicine therapy, medication errors and nursing assistance.

Concerning the ethical aspects, the making of the research took in consideration four basic principles of bioethics which comprehend autonomy, non-maleficence, beneficence and justice, aiming at ensuring the rights and duties related to scientific community and to the subjects of the research ${ }^{(9)}$. So, the project of research was sent to the Committee of Ethics in Research of the Universidade Federal do Rio Grande do Norte, Brazil, being analyzed and a favorable ordinance was issued through the number of the process 170.355 .

\section{Results}

Concerning the characterization of the participants, most of the interviewees were female (84\%), the average age was 50 years, ranging from 23 to 64 years. As to the marital status, $44 \%$ were single, $32 \%$ married and $24 \%$ in a stable relationship. Related to schooling $52 \%$ of the interviewees had complete high school, $36 \%$ complete university and $12 \%$ incomplete university.

When questioned on the time of work in the area of nursing, the answers varied between one and 39 years, with an average of 28.36 years. Concerning the time of work at the institution researched, it ranged between one and 34 years, with an average of 24.16 years. As to the sector of work, $36 \%$ worked in pediatrics, $28 \%$ in the surgical center, $24 \%$ in the joined rooming and $12 \%$ in the delivery room. Only $8 \%$ reported to work in a hospital institution and $24 \%$ reviewed to have more than one source of income distinct of the area of health, besides the one obtained as a nursing professionals.

When asked on the visual alterations, once these could jeopardize the preparation of the medicine, $40 \%$ reported to be myopic, $20 \%$ had astigmatism, $8 \%$ hyperopia and $8 \%$ myopia associated to astigmatism. All the health professionals with alteration in the vision used visual correction through glasses. Only $24 \%$ of the interviews did not have any eye problem.

Concerning the number of medicine prepared per day, considering a shift of 12 hours, $44 \%$ of the subjects reported an average of 10 times, 28\% 
reported from six to nine times, $20 \%$ from two to five times and $8 \%$ just once. Concerning the venue of preparation of the medicine, $36 \%$ of the deponents reported that, because there was no exclusive venue in the institution to make this procedure, it was made in the sink of the nursing station. Regarding lighting of the nursing station $52 \%$ considered it good.

Regarding the difficulties related in the preparation of medicine, from the analysis of the reports the following was highlighted: the medical prescription was made by hand and the writing was little legible. Such fact is shown in the reports as follows: First, there are doctors who have handwriting which we can't understand, the handwriting is very bad. Sometime he writes a 'two' and we don't know if it's an 'eight' (E16). We must guess what is written in the doctor's handwriting. We have to look for a nurse to decipher what is written in the prescription (E24).

Afterwards, the problem in identifying precisely the nomenclature of the medicine written on the containers emerged from the report. This situation occurs because the containers and the labels of the medicines have letters with small font and similar containers, according to what is evident in the reports as follows: The labels of the medicine which have the color almost equal to the color of the ampoules. There is medicine with similar labels, and if we don't pay attention we make errors; the size of the letters of the labels is too small making reading difficult (E17); problems with identification of some medicine (small letters, obfuscating the names when reflected with the light, different medicine with similar identification) (E8).

The improper venue for the preparation of medicine or the lack of a specific place for this purpose is considered another obstacle. Besides that, the deponents also mentioned the conversation and distraction as a factor which predisposes the occurrence of error and the preparation of medicine as well as the excess number of people and noise in the nursing station, as shown in the report as follows: the difficulties are the number of people in the nursing stations, the conversation, the flow of people, the noise. The nursing station is in the hall. Other health professionals go in all the time in the station to use the phone, to sit down, to assist the patient. The doctor's visit is here. They call us all the time. You are preparing the medicine and people keep calling the whole time (E9). Many times I am preparing a medicine and I am called to provide assistance in the ward, to answer the telephone, to receive a patient that is arriving, among other things. This makes you decentralize and make an error (E5).

There are still problems such as the sending of wrong medicine by the drugstore and the disorganization in the storage of the medicine in the nursing station. It was also observed that the nursing professionals consider the access of attributions/functions and the high number of medicine to be prepared as factors which represent disorders/obstacles in the preparation of medicine.

With less frequency, other difficulties were mentioned by the nursing professionals, such as: beds with deficient identification or without identification; different kinds of administration of medicine such as intramuscular, intravenous, oral and subcutaneous; lack of knowledge on the medicine, especially on the validity of the medicine after preparation; system of collective distribution; lack of communication in the team; lack of visual clarity.

\section{Discussion}

The process of preparation and administration of the medicine in a hospital organization can be defined as a complex system, once it has many interlinked stages, which are interdependent and made by different health professionals who share a common objective: the rendering of the assistance to the health of the patients with quality, efficiency and safety. Within this multi-professional team, the nursing professionals, specifically the nursing professionals and their assistants are highlighted, once they form the major working force in the area of health worldwide ${ }^{(10)}$.

In Brazil, in 2010, the number of nursing professionals encompassed 1,449,583 subjects, of those $43.18 \%$ are nursing technicians and $36.8 \%$ are 
assistants, which is more than half of the category. The major part involves subjects in the age range of 26 to 55 years, being $86.85 \%$ female and most of them single or married ${ }^{(11)}$, in consonance with the data of the present research.

In this context, the nursing professionals mentioned above, are responsible for the correct preparation and administration of medicine, which is vital for the safe medicine assistance, once it can cause errors of medication. The error of medication is understood as any avoidable occurrence caused by the inadequate use of medicine. It is worth highlighting that its improper use can cause damage to the patient, even if the medicine is under the control of health professionals or of the patient ${ }^{(12)}$.

Most errors of medicine happen in the process of preparation and administration. The main errors observed were concerning the omission in the dose, the schedule and the technique of administration. Such errors were more expressive when antineoplastic, immunomodulators, anti-effectives were used ${ }^{(13)}$. Concerning the behavior adopted by the nursing professionals facing the occurrence of the error, their omission is highlighted, which happens because of the non-recognition of having made the error and/or by fear all the consequences inherent to the act and by guilt ${ }^{(14)}$.

Under this perspective, the difficulties experienced by the nursing professionals during the preparation of medicine can be determinant for the occurrence of errors. Thus, in this study, the main problem experienced by the nursing technicians during the preparation of medicine involved the handwritten medical prescription, whose handwriting did not favor its comprehension. This fact confirms the results found in another study, in which, among the 441 medical prescription investigated during the period of one month, 363 had some kind of error, of which, 166 were linked to the illegibility of the prescription and five with erasures ${ }^{(15)}$. A multicentric research identified 1,425 errors related to medicine, being 215 inherent to the dosage, involving acronyms and abbreviations in the prescriptions, lack of the register of the patient, lack of the posology and suppression of the date $\mathrm{e}^{(16)}$.

So, in the situation of eligible medical prescription, the nursing technicians must ask for a second opinion in case there is persistence in the doubt, they must contact their supervisor or nurse. If the problem is not solved, a consultation of the previous prescription can be made. And if the doubt still remains, the medical teams must be called ${ }^{(17)}$. Under this perspective, the use of a computerized system for the prescription of the therapeutics, makes it safer, once the prescription will be presented legible and standardized ${ }^{(18)}$.

Besides the prescription of medicine, the nursing professionals mentioned the difficulty in the correct identification, once they have containers with a reduced size, with similar colors and shapes and with small letters, a fact that enhances the possibility of errors. Such assertive is reinforced by a study in which $43 \%$ of the evaluated medicines were considered potentially similar, due to the fact that the labels or packages presented similarities, contributing for the occurrence of errors in the process of preparation of medicine ${ }^{(17)}$.

Due to the similarity of the medicine and the factors of risk related to the wrong preparation of those, there is a wide discussion on the importance of the implantation of the system of distribution of medicine using individual doses, thus avoiding inadequacy and guarantee more safety to the medicine therapeutics ${ }^{(17)}$. However, this proposal involves other aspects which must be considered, such as the expansion of drugstore staff. Associated to that, there are ethical questions involved, once the nursing professionals cannot be responsible for medicine not prepared by them.

Furthermore, the presence of interruptions, level of high or frequent noise and the difficulty for storage of the medicine is highlighted as a difficulty. 
This situation matches the lack of an area reserved for the preparation of medicine, which collaborates for the occurrence of distractions and interruptions. A study reveals that the venue of preparation of medicine must be organized, with adequate lighting, with little noise in order to prevent the occurrence of errors, however, this reality is not very frequent in those institutions ${ }^{(18)}$ and in the hospital researched, in which the health professionals revealed the inexistence of an exclusive venue for the preparation of medicine. Besides that, the lack of guidelines and institutional protocols having as target the preparation of medicine and other related arrangements are highlighted ${ }^{(19)}$.

Another unfavorable factor is the unpreparedness of the nursing professionals concerning the aspects which involve medication. Among those, the lack of information on the preparation and administration of medicine, overload and bad conditions of work are highlighted, reflecting in errors of calculation, preparation and administration ${ }^{(2)}$. Regarding the unpreparedness, studies report that a large number of technical schools working with inadequate physical structure and with a non-satisfactory faculty, reflects in the education of technicians who are not always qualified, and the permanent education of these professionals in the institution in which they work is fundamental, aiming at solving this problem ${ }^{(20)}$. In this aspect, it is worth highlighting that in the present research $36 \%$ of the nursing technicians had university education and $12 \%$ were studying at the university, a reality which shows the search of these professionals for better conditions of teaching and technical and scientific preparedness.

A study adds as the cause of medicine errors, the lack of attention, associated to the inexperience of some professionals and to the structural problems of some institutions ${ }^{(20)}$. In this aspect, the inexperience cannot be mentioned as a problem in this study, keeping in mind that the average of working time in the area of nursing was 28.36 years.

The investigated subjects also highlighted the excess of functions, as well as the large quantity of medicine to prepare as one of the difficulties experienced, bearing in mind that the major part of the sampling prepared the medicine in a shift of 12 hours, at least 10 medicines. Besides that, the major part works in Pediatrics and in the Surgical Center, places that require a greater attention and work. A research asserts that when associating to the overload, the lack of experience and attention, the probability of occurring an error increases, resulting from the accelerated pace of work required by the health institutions, the high number of professionals incapable of supplying the demand of care to the patient, as well as the deficit of remuneration, which induces to the search of other institutions in order to improve the income ${ }^{(20)}$. Under this perspective, this reality is verified in this study in question, once $8 \%$ of the technicians work in other hospital institutions and $24 \%$ have another source of income which is not nursing.

The errors resulting from the expedition of medicine by the drugstore is highlighted in this study as an experienced problem. It is known that the drugstores have as main attribution the adequate expedition of medicine, which must be distributed commonly according to the medical prescription. However, many errors in expedition of the medicine occur and are not detected, and even if they do not cause serious consequences to the patients, once most of them is detected in time by the nursing professional must be investigated, once they are part of an important stage in the medicine process ${ }^{(21)}$.

Other difficulties mentioned by the nursing professionals, despite having been detected with minor frequency, are considered important causes of errors in the medicine therapeutics, as follows: beds with deficient identification or without identification; different kinds of administration of medicine; system of collective distribution; lack of communication in the team, lack of visual clarity.

It is known that the correct identification of 
the patient as well as the effective communication is part of the 10 steps for the safety of the patient. The inaccurate identification can cause errors not only of medicine but also in the transfusion of blood components, in diagnosis test, procedure in wrong venues, among others. In this sense, in order to have correct identification they must use not only the number of the beds of the patient, which not always have satisfactory identification, therefore, they must use identification bracelets, medical records, tags and the participation of patients and family members for the confirmation of their names ${ }^{(22)}$.

Regarding the communication, when it is inefficient, it can generate medicine errors by the nursing team which can be resulting from faults in the prescription, in the transcript or among the teams, being of vital importance that the nursing team is aware of these aspects ${ }^{(18)}$. The collective distribution besides confusing the nursing technicians at the moment of the distribution to the patient, if each medicine is not well identified, generates a great number of medicine which are not used by the patients, increasing the stocks of medicines in the sector, that can reverberate in errors in the administration of medicine, misplacement, inappropriate packaging and loss of medicine because of due validity, generating more expenses for the hospital ${ }^{(23)}$.

Concerning the visual alteration, most of the investigated subjects presented some alterations; however, all of them use visual correction. So, it is understood that the errors related to lack of visual clarity are solved by the use of correction lenses, having no reverberation in the professional work.

In this sense, the nursing technicians must make the preparation and administer the medicine focusing on the basic requirements which guarantee the absence of damage to the patient. So, the development of strategies which favor the safe care regarding the medicine therapeutics is indispensable. Keeping in mind that the occurrence of medicine error can provoke damages not only to the patients, but also to the professionals who take care of them and to the health institutions ${ }^{(20)}$.

\section{Conclusion}

The nursing technicians experienced difficulties to make the correct preparation of medicine, related to the organizational, physical-structural and professional aspects.

Regarding the organizational aspects, the occurrence of eligible medical prescription or little legible was observed, as well as problems in the distribution of medicine and few human resources. As to the physical-structural aspects, the labels of the similar medicine are highlighted, as well as the lack of a proper venue for the preparation of medicine and precarious lighting.

It is concluded that the medicine therapy and, especially, the safety of the patient are not totally exempt of risks resulting from several factors which are interlinked. So, the complete humanized assistance free of damage to the health of the user is not guaranteed in its totality.

The errors are part of the human condition and will always exist, considering the incompleteness of the human being, the movements of changes and continued improvement of the species. However, it is necessary to have the development of a culture of the safe care with the idea of minimizing errors and, consequently, damages to the health of the patients.

\section{Collaborations}

Azevêdo O, Silva CMB and Araújo LJDP contributed for the conception of the study, data collection, analysis, interpretation of the data and writing of the manuscript. Costa EO, Fernande MICD and Lira ALBC contributed for the final conception, writing of the manuscript and final approval of the version. 


\section{References}

1. Leal AA, Reis DS, Silva ALF, Barbosa AC. A iatrogenia na enfermagem. Rev Eletr UNIVAR [Internet]. 2013 [citado 2014 jun 20]; 1:102-8. Disponível em: http://www.revista.univar.edu. br/index.php/interdisciplinar/article/view/62.

2. Praxedes MFS, Filho PCPT. Erros e ações praticadas pela instituição hospitalar no preparo e administração de medicamentos. Rev Min Enferm. 2011; 15(3):406-11.

3. Arboit AL, Silva LAA. Eventos adversos relacionados à terapia medicamentosa na enfermagem. Rev Enferm. 2012; 8(8):140-53.

4. Coli RCP, Anjos MF, Pereira LL. The attitudes of nurses from an intensive care unit in the face of errors: an approach in light of bioethics. Rev Latino-Am Enfermagem. 2010; 18(3):324-30.

5. Ministério da Saúde (BR). Agência Nacional de Vigilância Sanitária, Agenda Nacional de Prioridades de Pesquisa em Vigilância Sanitária. Brasília: Ministério da Saúde; 2011.

6. Minayo MCS. Pesquisa social: teoria, método e criatividade. 29ª ed. Petrópolis: Vozes; 2010.

7. Fontanella BJB, Luchesi BM, Saidel MGB, Ricas J, Turato ER, Melo DG. Amostragem em pesquisas qualitativas: proposta de procedimentos para constatar saturação teórica. Cad Saúde Pública. 2011; 27(2):389-94.

8. Bardin L. Análise de conteúdo. São Paulo: Edições 70; 2011.

9. Ministério da saúde (BR). Conselho Nacional de Saúde, Comissão Nacional de Ética em Pesquisa. Resolução no 466/2012 de 12 de dezembro de 2012: aprova as diretrizes e normas regulamentadoras de pesquisa envolvendo seres humanos. Brasília: Ministério da Saúde; 2012.

10. Cheregatti AL, Jeronimo RAS, organizadores. Administração de medicamentos: 5 certos para segurança do paciente. $2^{\mathfrak{a}}$ ed. São Paulo: Rideel; 2010.

11. Conselho Federal de Enfermagem. Comissão de business intelligence. Análise dos dados dos profissionais de enfermagem existentes nos Conselhos Regionais. Conselho Federal de Enfermagem; 2011.
12. National Coordinating Council for Medication Error Reporting and Prevention [Internet]. What is medication error? [Internet] 2013 [cited 2013 nov 11]. Disponível: http://www.nccmerp.org/ public/aboutmederror.htm

13. Silva AEBC, Reis AMM, Miasso AI, Santos JO, Cassiani SHB. Adverse drug events in a sentinel hospital in the state of Goiás, Brazil. Rev LatinoAm Enfermagem. 2011; 19(2):378-86.

14. Silva LD, Passos RS, Carvalho MF. Características e evidências da produção científica de enfermeiros sobre erros de medicação no ambiente hospitalar. Rev Rene. 2012; 13(2):480-91.

15. Lins BG, Cazzamalli F, Zancanaro V. Análises de erro nas prescrições médicas de uma unidade. Rev Interd Estud Saúde. 2012; 1(2):62-77.

16. Gimenez FRE, Mota MLS, Teixeira TCA, Silva AEBC, Opitz SP, Cassiani SHB. Patient safety in drug therapy and the influence of the prescription in dose errors. Rev Latino-Am Enfermagem. 2010; 18(6):1055-61.

17. Lopes DMA, Néri EDR, Madeira LS, Neto PJS, Lélis ARA, Souza TR, et al. Análise da rotulagem de medicamentos semelhantes: potenciais erros de medicação. AMB Rev Assoc Med Bras. 2012; 58(1):95-103.

18. Santana JCB, Sousa MA, Soares HC, Avelino KSA. Fatores que influenciam e minimizam os erros na administração de medicamentos pela equipe de enfermagem. Enferm Rev. 2012; 15(1):122-37.

19. Veloso IR, Telles Filho, PCP, Durão AMS. Identificação e análise de erros no preparo de medicamentos em uma unidade pediátrica hospitalar. Rev Gaúch Enferm. 2011; 32(1):93-9.

20. Lopes BC, Vargas MAO, Azeredo NSG, Behenck A. Erros de medicação realizados pelo técnico de enfermagem na UTI: contextualização da problemática. Enferm Foco. 2012; 3(1):16-21.

21. Galvão AA, Oliveira AM, Carvalho FB, Araújo RPC. Identificação e distribuição dos erros de dispensação em uma farmácia hospitalar: um estudo comparativo no município de Salvador Bahia. Rev Ciênc Méd Biol. 2012; 11(1):201-6.

22. Conselho Regional de Enfermagem do Estado de São Paulo. Rede Brasileira de Enfermagem e Segurança do Paciente. 10 passos para a segurança 
do paciente. Conselho Regional de Enfermagem; 2010.

23. Vasconcelos ACP, Sena PS, Souza HN, Lima CM, Rios MC. Sistema de distribuição coletiva de medicamentos: uma análise de caso sob a ótica da eficiência. Rev Bras Farm. 2012; 93(4):499-503. 